\title{
STATUS TEKNOLOGI PENANGKAPAN IKAN DEMERSAL DAN KEMUNGKINAN PENGEMBANGANNYA DI KABUPATEN LOMBOK BARAT
}

\author{
Agustinus Anung *) dan H.R. Barus*)
}

\begin{abstract}
ABSTRAK
Aktivitas penangkapan ikan demersal yang dilakukan nelayan di Kabupaten Lombok Barat terkonsentrasi di daerah perairan Selat Lombok. Sumber daya perikanan demersal yang terdapat di perairan tersebut antara lain kakap (Lutjanus spp.), kerapu (Ephinephelus spp.), manyung (Arius spp.), cucut (Carcarinus spp.), bawal putih (Pampus argentius) dan beloso (Saurida spp.). Usaha penangkapan umumnya dilakukan secara tradisional. Alat tangkap yang digunakan antara lain pancing ladung, bubu, jaring klitik dan rawai dasar.

Penelitian tentang status teknologi alat tangkap ikan demersal di Lombok Barat telah dilakukan pada bulan Maret 1994. Hasil pengamatan menunjukkan bahwa kinerja dari teknologi tersebut di atas umumnya belum baik. Hal tersebut mengakibatkan produktivitasnya rendah. Pengembangan yang dapat dilakukan adalah dengan cara melakukan perbaikan karakteristik alat tangkap, cara penangkapan, menambah jumlah alat tangkap per unit usaha, dan memperbesar ukuran kapal.
\end{abstract}

\begin{abstract}
Status of Demeral Fishing Technology and Its Poscible Development in West Lombot, West Nusa Tenggara, by: Agustivus Anung and H.R. Bernus.
\end{abstract}

Fishing activity of demersal fishes in West Lombok is concentrated at Lombok Strait. The demersal fishes commonly found are: Lutjanus spp, Ephinephelus spp., Arius spp., Carcarinus spp., Pampus spp., and Saurida spp. Fishing activity is practiced by using traditional gears, such as: hand line, trap, bottom gillnet and bottom long line. Research on the status of demersal fishing technology in West Lombok was carried out in March 1994. Result of the observation shows that the existing gears are still low in catchability, causing low productivity. Improvement of fishing gear characteristics (design and construction), improvement of fishing methods as well as increasing number of gears and size of fishing vessels are some efforts that have to be implemented for developing the fisheries in this area.

KEYWORDS: Fisbing tecbmology, demersal fisb, fisbing gear

\section{PENDAHULUAN}

Kegiatan usaha pada subsektor perikanan laut, khususnya di bidang penangkapan ikan di Kabupaten Lombok Barat telah lama berlangsung dan daerah penangkapannya terkonsentrasi di perairan Selat Lombok. Sumber daya perikanan demersal yang terdapat di perairan ini antara lain adalah jenis ikan kakap (Lutjanus spp.), kerapu (Ephinepelus spp.), manyung (Arius spp.), cucut (Carcarinus spp.), bawal putih (Pampus spp.), dan beloso (Saurida spp.).

") Peneliti pada Balai Penelitian Perikanan Laut, Jakarta 
Beberapa jenis ikan tersebut mempunyai nilai ekonomi yang tinggi, bahkan jenis kakap dan kerapu merupakan komoditas ekspor yang cukup penting.

Jenis alat tangkap yang banyak digunakan nelayan di wilayah Kabupaten Lombok Barat dalam usaha perikanan demersal adalah: pancing ladung/pancing tangan (band line), bubu (trap), jaring klitik (monofilament bottom gillnet) dan rawai dasar (bottom long line) (Dinas Perikanan Kabupaten Lobar, 1993). Jenis sarana penangkapan yang digunakan adalah perahu layar (90\%), perahu motor tempel $(8,9 \%)$ dan kapal motor $(1,1 \%)$. Ukuran perahu maupun kapal motor tersebut semuanya lebih kecil dari 5,0 GT dengan kekuatan motor antara 3,5-10,0 HP.

Rata-rata produktivitas alat tangkap ikan demersal di Lombok Barat umumnya lebih rendah dari rata-rata produktivitas alat tangkap ikan demersal di Indonesia (Table 1). Rendahnya produktivitas tersebut diduga disebabkan rendahnya tingkat teknologi penangkapan yang menyangkut karakteristik (desain dan konstruksi) alat tangkap, strategi (metode, alat bantu dan manajemen) penangkapan dan sarana penangkapan.

Table 1. Average catch rates of demersal fish in West Lombok and Indonesia 1992

\begin{tabular}{|c|c|c|c|c|c|c|}
\hline \multirow[t]{2}{*}{ Types of fisbing sears } & \multicolumn{3}{|c|}{ West Lombok") } & \multicolumn{3}{|c|}{ Indonesia } \\
\hline & $\begin{array}{c}\text { Number } \\
\text { (mnit) }\end{array}$ & $\begin{array}{c}\text { Volume } \\
\text { (tom) }\end{array}$ & $\begin{array}{l}\text { Production } \\
\text { per nnit } \\
\text { (ton) }\end{array}$ & $\begin{array}{c}\text { Number } \\
\text { (nnit) }\end{array}$ & $\begin{array}{l}\text { Volume } \\
\text { (ton) }\end{array}$ & $\begin{array}{l}\text { Production } \\
\text { per winit } \\
\text { (con) }\end{array}$ \\
\hline A. DEMERSAL FISHES & & & & & & \\
\hline 1. Hand lines & 3,366 & $1,390.4$ & 0.413 & 145,143 & 184,843 & 1,343 \\
\hline 2. Trap & 141 & 62.3 & 0.442 & 8,987 & 17,590 & 1,957 \\
\hline 3. Bottom gillnet & 96 & 60.3 & 0.634 & 46,362 & 139,926 & 3,016 \\
\hline 4. Bottom long lines & 11 & 120.7 & 10.973 & 12,788 & 50,622 & 3,956 \\
\hline $\begin{array}{l}\text { B. DEMERSAL AND } \\
\text { PELAGIC FISHES }\end{array}$ & & & & & & \\
\hline 1. Encircling gillnet & 10 & 273.4 & 27.340 & 9,557 & 51,226 & 5,360 \\
\hline 2. Beach seine & 71 & 331.9 & 4.674 & 10.278 & 94,966 & 9,239 \\
\hline
\end{tabular}

Guna memenuhi kebutuhan pangan (gizi) masyarakat dan permintaan pasar yang terus bertambah, maka peningkatan produksi perikanan perlu terus dilakukan. Di Indonesia Bagian Timur tingkat pemanfaatan sumber daya beberapa jenis ikan demersal masih rendah, seperti kakap merah baru mencapai $33,5 \%$, bawal putih $26,0 \%$ dan manyung $18,3 \%$ (Widodo et al., 1991). Dilihat dari keberadaan sumber daya tersebut, maka untuk memacu peningkatan produksi perikanan, ikan demersal mempunyai peluang yang tinggi. Namun 
dibalik peluang tersebut, tantangan yang harus segera dijawab yaitu dilakukannya pengembangan teknologi penangkapan yang selama ini telah ada sehingga mempunyai performansi yang lebih baik agar produktivitasnya tinggi.

Penelitian ini dimaksudkan untuk mendapatkan gambaran mengenai tingkat teknologi penangkapan ikan demersal di Lombok Barat. Tulisan ini membahas hasil penelitian tersebut di atas dan kemungkinan pengembangan yang dapat dilakukan.

\section{BAHAN DAN METODE}

Penelitian ini dilakukan di wilayah sentra usaha perikanan di Kabupaten Lombok Barat (Kecamatan Bayah, Gangga, Tanjung, Gunungsari, Ampenan, Labuapi, Gerung dan Sekotong) pada bulan Maret 1994. Data primer didapat dengan cara pengamatan langsung (observasi). Terhadap setiap jenis alat tangkap pada usaha perikanan demersal (pancing ladung, bubu, jaring klitik dan rawai dasar) milik nelayan dilakukan pengukuran dan pengamatan yang meliputi: dimensi, bahan dan konstruksinya. Data mengenai sarana penangkapan kapalnya didapat dengan cara mengukur dimensi yang meliputi: panjang (L), lebar (B) dan dalam (D) serta tenaga penggeraknya. Selanjutnya data mengenai aspek operasional dan hasil tangkapan didapat dari pengamatan dengan mengikuti secara langsung kegiatan operasi penangkapan di laut. Data pendukung diambil dari laporan Statistik Perikanan Dinas Perikanan Dati II Kabupaten Lombok Barat tahun 1993.

\section{HASIL DAN PEMBAHASAN}

Jenis alat tangkap ikan demersal yang banyak digunakan nelayan di Kabupaten Lombok Barat adalah pancing ladung/pancing tangan (3.366 unit), bubu (3.518 unit), jaring klitik (96 unit) dan pancing rawai dasar (11 unit). Teknologi dari masing-masing alat tangkap tersebut tergolong masih tradisional. Sarana penangkapan yang digunakan adalah perahu (kapal) dengan ukuran lebih kecil dari 1 GT dengan tenaga penggerak antara 3-8 $\mathrm{HP}$, sehingga hanya mampu melakukan kegiatan penangkapan di daerah pinggiran saja (pantai). Hal inilah yang diduga sebagai penyebab rendahnya produktivitas alat tangkap ikan demersal di Lombok Barat.

\section{Pancing I adung (Hand Line)}

Jenis alat tangkap ini sangat populer, dan penyebarannya menyeluruh di semua sentra perikanan di Kabupaten Lombok Barat. Sasaran utama alat tangkap ini adalah jenis ikan kakap, kerapu dan cucut. Deskripsi umum pancing ladung, untuk menangkap ikan kakap dan kerapu, tali pancing terbuat dari benang monofilament (senar) nomor 1000-1500 atau diameter 1,5-2,0 mm. Mata pancing yang digunakan adalah tipe punggung lurus ("J-type") dengan ukuran nomor 5,0-7,0 dan jumlahnya $2-3$ buah pada setiap unitnya. Pemberat 
dari bahan timah $0,5 \mathrm{~kg}$. Umpan yang digunakan adalah ikan pelagis kecil (selar atau kembung). Pancing dioperasikan pada kedalaman 30-100 m. Sedangkan untuk menangkap cucut, tali pancing adalah senar nomor 4000 atau diameter 2,5 mm. Mata pancing ukuran (nomor) 3,0. Pada ujung tali pancing dipasang tali pelindung dari bahan kawat monel diameter $0,5-1,0 \mathrm{~mm}$ dan panjang $0,75-1,0 \mathrm{~m}$. Antara tali pancing dan tali pelindung dipasang kili-kili ukuran $3 / 8$ inci. Pemberat dari bahan timah dengan bobot 0,8-1,0 kg. Setiap unit pancing hanya dipasangi satu buah mata pancing. Umpan umumnya dari daging sapi, kuda atau kerbau, khususnya bagian lidah. Pancing dioperasikan hingga kedalaman air $400 \mathrm{~m}$. Sarana pengoperasian berupa perahu layar dan motor. Ukuran perahu panjang (L) 6,0-7,5 m, lebar (B) $0,65-0,70 \mathrm{~m}$ dan dalam (D) 0,50-0,65 m atau 0,41-0,72 GT dengan motor berkekuatan 3,5-8,0 HP. Jumlah nelayan pada perahu pancing ladung umumnya 2 orang. Sistem trip adalah harian dengan rata-rata hasil tangkapan $6 \mathrm{~kg}$ ikan demersal dan $15 \mathrm{~kg}$ ikan cucut.

Secara teknis pancing ini memang sangat cocok untuk menangkap ikan-ikan demersal seperti halnya kakap, kerapu dan cucut. Produktivitas per unit pancing ladung memang terlihat kecil, yaitu antara $6.15 \mathrm{~kg} / \mathrm{hari}$. Namun karena jumlah unit jenis pancing di Lombok Barat cukup banyak (3.366 unit), maka hasil tangkapan secara kumulatif menjadi tinggi. Cara pengembangan yang paling cocok pada jenis alat tangkap ini adalah dengan cara memperbaiki manajemen usaha penangkapannya, yaitu dengan mengembangkan sistem pola armada semut seperti yang telah dilakukan pada perikanan pancing tangan untuk menangkap tuna di daerah Sorong (Irian Jaya).

\section{Bubu (Trap)}

Jenis bubu yang dioperasikan nelayan Kabupaten Lombok Barat adalah bubu bambu dengan bentuk persegi empat. Hasil tangkapan utama alat ini adalah kakap, kerapu dan udang barong (lobster). Alat tangkap bubu di Kabupaten Lombok Barat hanya dioperasikan oleh nelayan di wilayah Kecamatan Tanjung dan Ampenan. Terdapat 2 ukuran bubu, yaitu kecil dan besar. Bubu kecil berukuran $0,8 \times 0,6 \times 0,5 \mathrm{~m}^{3}$ dan bubu besar berukuran $1,5 \times 0,9 \times 0,6 \mathrm{~m}^{3}$. Bubu ini dioperasikan tanpa menggunakan umpan dan tidak dirakit (sendirisendiri). Bubu dioperasikan pada perairan dengan kedalaman mencapai $40 \mathrm{~m}$. Bubu ukuran kecil dioperasikan dan diangkat setiap hari. Sedangkan pada bubu besar biasanya dilakukan pengangkatan setiap 3 hari sekali. Jumlah bubu setiap unit penangkapan antara 6-8 buah. Hasil tangkapan rata-rata pada bubu kecil $0,8 \mathrm{~kg} / \mathrm{bubu} / \mathrm{hari}$, sedangkan pada bubu besar rata-rata mencapai 1,1 $\mathrm{kg} / \mathrm{bubu} / \mathrm{hari}$. Sarana operasional berupa perahu (jukung) dengan ukuran panjang (L) 6,0-6,5 m, lebar (B) 0,65-0,70 m dan dalam (D) 0,50-0,60 $\mathrm{m}$ atau $0,40-0,60$ GT. Tenaga penggerak umumnya berkekuatan 3,5 HP. Jumlah nelayan yang mengoperasikan 2 orang. 
Salah satu faktor yang mempengaruhi keberhasilan alat tangkap tersebut adalah penentuan koefisien pengikatan yang tepat. Dikatakan bahwa koefisien pengikatan jaring insang dasar adalah berkisar 50\% (Fridman, 1973). Dengan koefisien pengikatan seperti tersebut di atas, maka dapat dikatakan bahwa jaring klitik di Kabupaten Lombok Barat mempunyai desain cukup baik. Pengaruh dari hal tersebut adalah produktivitasnya yang cukup tinggi, yaitu $1,2 \mathrm{~kg} /$ tinting/tawur. Jumlah tersebut memang masih lebih rendah dibanding jaring klitik yang dioperasikan di perairan Pacitan, yaitu sekitar 1,4 kg/tinting/ tawur (Barus dan Nasution, 1983). Hasil penelitian yang dilakukan Atmaja (1994) menunjukkan bahwa cahaya lampu dapat digunakan sebagai alat bantu penangkapan ikan demersal dengan jaring klitik. Oleh karena itu, pengembangan teknologi penangkapan ikan demersal dengan jaring klitik di Kabupaten Lombok Barat dapat mengacu pada hasil penelitian tersebut. Selain itu, jumlah tinting jaring setiap unitnya seyogyanya ditambah menjadi 20-30 tinting. Selanjutnya ukuran kapal juga harus diperbesar hingga 5 GT dengan tenaga penggerak sekitar $22 \mathrm{HP}$.

\section{Rawai Dasar (Bottom Long Line)}

Alat tangkap rawai dasar di Kabupaten Lombok Barat baru berkembang di wilayah Kecamatan Ampenan, Labuapi dan Gerung. Hasil tangkapan antara lain adalah jenis ikan kakap, kerapu, bubara, cucut dan manyung. Deskripsi umum dari rawai dasar yang dioperasikan nelayan di wilayah tersebut di atas adalah:' tali utama (main line) terbuat dari bahan PA monofilament (senar) nomor 3000-4000. Tali cabang (branch line) juga dari bahan senar, namun dengan nomor 800-1000. Mata pancing yang digunakan umumnya adalah nomor 6. Jarak pemasangan antar tali cabang adalah $3 \mathrm{~m}$. Panjang tali cabang antara 1,0-1,2 m. Jumlah mata pancing antara 100-200 buah pada setiap unitnya. Tali pelampung dari bahan PE diameter $6-7 \mathrm{~mm}$. Sarana penangkapan berupa perahu jukung dengan 2 katir. Ukuran perahu, panjang (L) 6,0-7,5 m, lebar (B) 0,6-0,7 $\mathrm{m}$ dan dalam (D) 0,55-0,65 $\mathrm{m}$ atau 0,42-0,72 GT. Tenaga penggerak adalah motor tempel berkekuatan 3,5-8,0 HP. Perahu ini umumnya diawaki oleh 2 orang nelayan. Pancing dioperasikan siang dan malam hari, dengan jumlah tawur rata-rata 2 kali sehari. Pancing dioperasikan pada perairan berkedalaman 30-200 meter. Umpan yang digunakan adalah ikan jenis lemuru. Laju tangkapan pancing rata-rata berkisar 3,0-4,0 dengan bobot total mencapai $50 \mathrm{~kg}$.

Dari segi desain dan konstruksi, rawai dasar yang dioperasikan nelayan di Kabupaten Lombok Barat telah memenuhi persyaratan teknis. Penggunaan tali monofilament (senar) sebagai bahan (material) tali cabang maupun tali utama adalah sangat baik. Sebab bahan tersebut bersifat transparan dan tidak mudah terlihat di dalam air. Menurut Prado dan Dremier (1990), salah satu syarat utama bahan untuk tali pancing rawai dasar adalah tidak mudah terlihat di 
Anung, A. dan Barus, H.R.

dalam air. Performansi yang baik dari rawai dasar yang dioperasikan nelayan Lombok Barat juga diindikasikan oleh laju tangkapan pancing yang cukup tinggi yaitu berkisar antara 3,0-4,0. Sebagai bahan perbandingan, laju tangkapan pancing rata-rata rawai dasar yang dioperasikan di perairan Utara Jawa adalah 3,0 (Wijopriono dan Latif, 1993).

Pengembangan yang dapat dilakukan pada alat tangkap ini adalah dengan cara memperbanyak jumlah mata pancing pada setiap unitnya hingga sekitar 3000 mata pancing. Sedangkan ukuran kapal diperbesar menjadi lebih besar dari 5 GT. Pada pengembangan selanjutnya, adalah diperkenalkannya penggunaan pesawat bantu penarik tali pancing berupa baby line hauler yang digerakkan dengan tenaga hidraulik berkekuatan 5-8 HP. Desain kapal rawai yang terdapat di Lombok Barat disajikan pada Figure 2a. Sedangkan desain kapal rawai dan pesawat bantu baby line bauler untuk kepentingan pengembangan disajikan pada Figure $2 b$ dan Figure $2 c$.

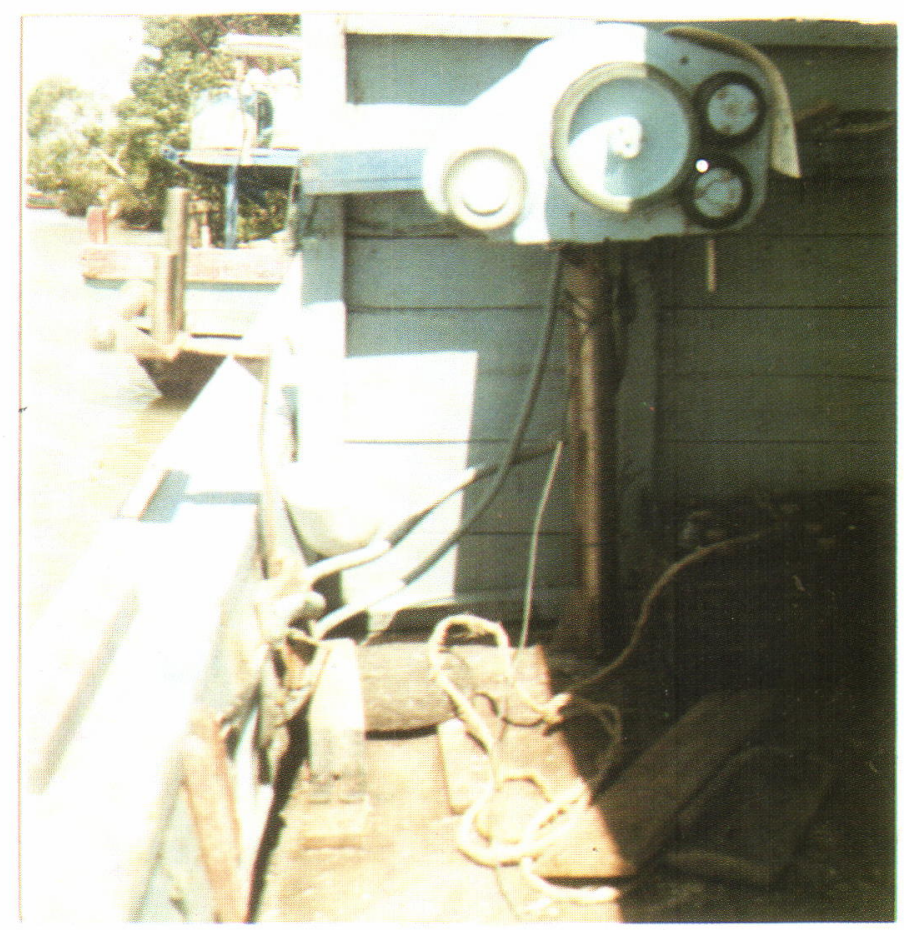

Figure 2a. Conventional bottom longliner in West Lombok 
Produktivitas bubu ikan demersal di Kabupaten Lombok Barat relatif rendah. Sebagai bahan perbandingan, bubu tipe Malaysia yang dioperasikan di perairan Natuna mencapai hasil tangkapan mencapai $5,15 \mathrm{~kg} / \mathrm{bubu}$ dengan waktu rendam (soaking time) 2-3 hari (Djamal dan Marzuki, 1984). Ini berarti produktivitasnya $1,71-2,52 \mathrm{~kg} /$ bubu/hari. Desain dan konstruksi bubu di Lombok Barat dan bubu tipe Malaysia dapat dilihat pada Figure $1 a$ and Figure 16. Salah satu faktor yang mempengaruhi keberhasilan usaha penangkapan ikan adalah ketepatan metode yang digunakan. Pada penangkapan dengan bubu, metode penangkapannya sangat dipengaruhi oleh tingkah laku ikan sebagai obyek penangkapannya (Hirayama dalam Reppie, 1989). Salah satu faktor yang menyebabkan masih rendahnya produktivitas bubu di Kabupaten Lombok Barat karena cara pengoperasiannya tidak menggunakan umpan. Jenis ikan yang dapat digunakan untuk umpan pada bubu adalah remang, kepala tuna dan lain-lain. Dijelaskan bahwa, ikan menerima dan memberikan respon terhadap keadaan sekelilingnya dengan beberapa inderanya, salah satunya adalah indera penciuman (Gunarso, 1985). Oleh karena itu, bau khas yang ditimbulkan oleh umpan yang dipasang pada bubu akan menimbulkan daya tarik pada ikan untuk memasuki bubu tersebut. Guna meningkatkan produksi alat tangkap bubu secara keseluruhan, maka jumlah bubu dapat ditingkatkan 20-30 buah/unitnya. Konsekuensinya, bahwa ukuran perahu/kapal sebagai sarana operasinya harus diperbesar hingga ukuran 5 GT dengan tenaga penggerak sekitar 22 HP. Dengan kapal ukuran tersebut, maka akan mampu membawa bubu sebanyak 20-30 unit serta mampu melakukan pelayaran yang lebih jauh.

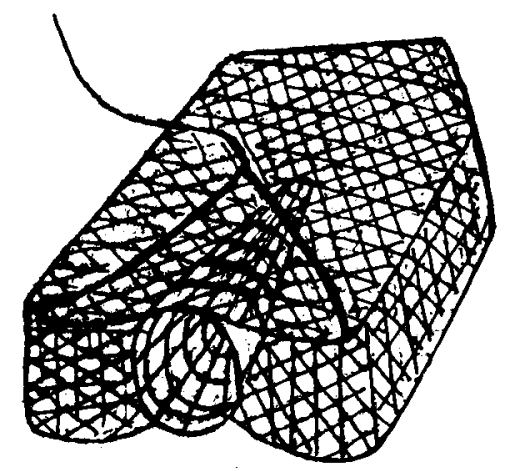

Figure 1a. Traditional trap in West Lombok

\section{Jaring Klitik (Monofilament Bottom Gillnet)}

Di Kabupaten Lombok Barat, alat tangkap ini banyak dioperasikan oleh nelayan di wilayah Kecamatan Ampenan dan Bayah. Hasil tangkapan antara lain ikan bloso, bawal dan manyung. Deskripsi umum 1 pis jaring klitik 


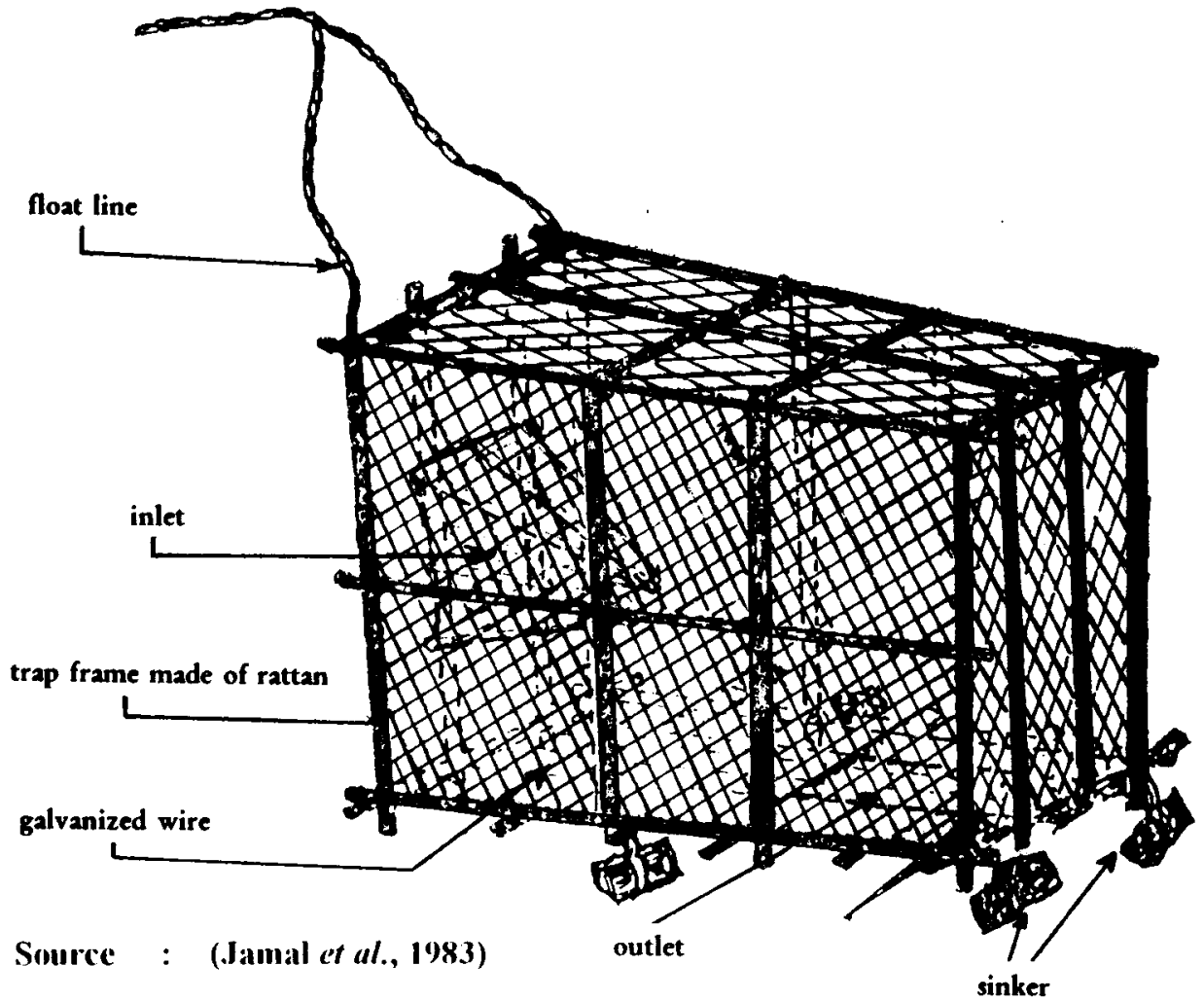

Figure 1b. Malaysian trap

tersebut adalah: badan jaring (webbing) bahan benang PA monofilament (senar) nomor 30-40 (diameter $0,5-0,8 \mathrm{~mm}$ ). Ukuran mata jaring $6,35-7,62 \mathrm{~cm}$. Jumlah mata ke bawah (mesh depth) 100 buah. Panjang jaring terpasang umumnya berkisar $32 \mathrm{~m}$. Koefisien pengikatan antara $50-60 \%$. Tali ris atas dan tali pelampung dari bahan PE dengan diameter masing-masing $5 \mathrm{~mm}$. Tali ris bawah maupun tali pemberat juga dari bahan PE, namun diameternya masing-masing adalah $3 \mathrm{~mm}$. Pelampung terbuat dari bahan karet sintetis tipe Y-2 sebanyak 36-40 buah. Pemberat dari bahan timah bentuk gendang dengan total bobot antara $2,0-2,3 \mathrm{~kg}$. Alat tangkap ini umumnya dioperasikan pada siang hari pada kedalaman perairan $20-40 \mathrm{~m}$. Trip penangkapan adalah harian dengan jumlah tawur per hari umumnya 2-3 kali. Sarana operasi penangkapan berupa perahu layar dan motor ukuran panjang (L) 6,00-7,50 m, lebar (B) 0,60-0,70 $\mathrm{m}$ dan dalam (D) $0,55-0,65 \mathrm{~m}$ atau $0,42-0,72 \mathrm{GT}$ dengan kekuatan motor penggerak antara 3,5-8,0 HP. Setiap perahu dioperasikan oleh 2 orang nelayan. Jumlah jaring yang digunakan antara 8-10 pis setiap unitnya. Hasil tangkapan rata-rata $1,2 \mathrm{~kg} / \mathrm{pis} / \mathrm{tawur}$. 

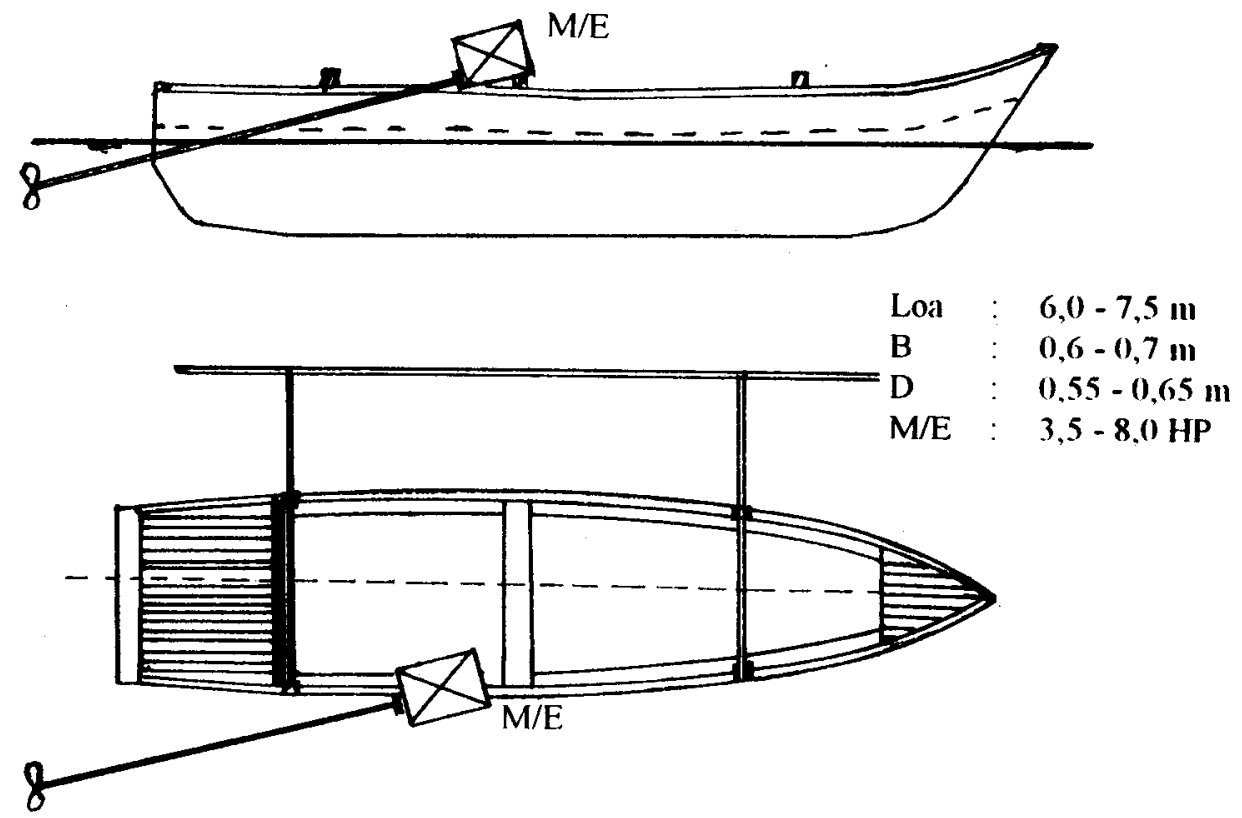

Source: Wijopriono et al., 1993

Figure 2b. Bottom longliner in West Lombok

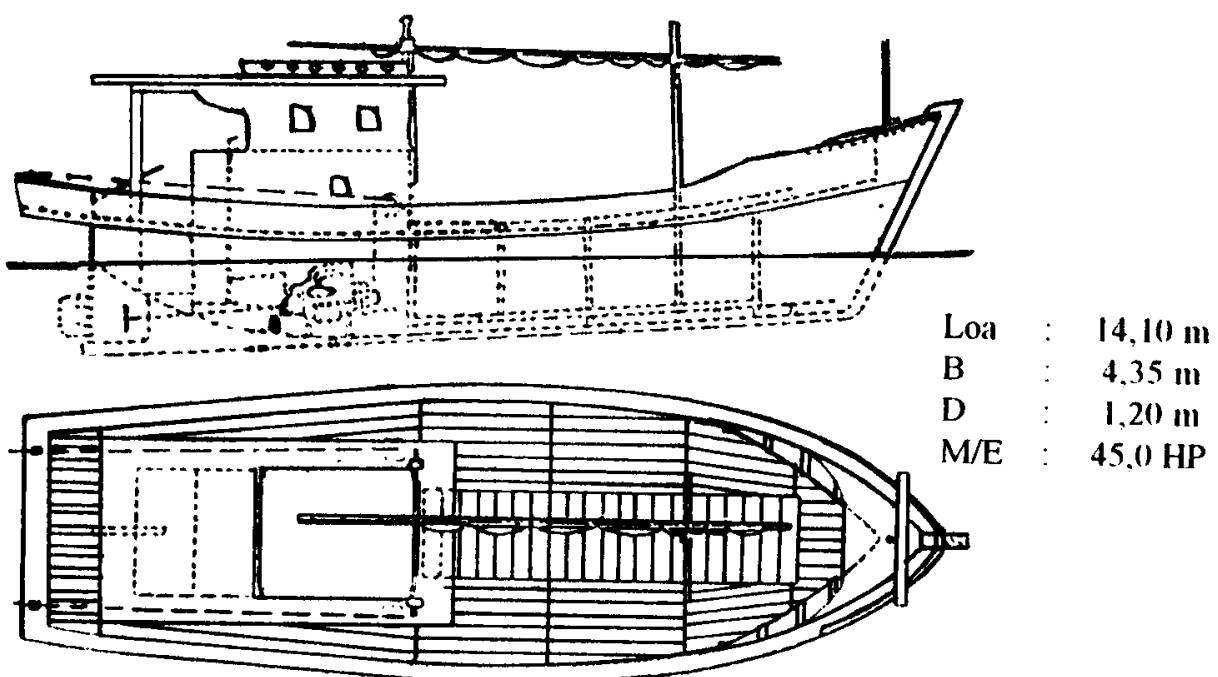

Source: Wijopriono et al., 1993

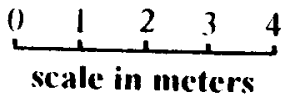

Figure 2c. Conventional bottom longliner in Java Sea 
Anung, A. dan Barus, H.R.

Dengan cara memperbesar ukuran kapal maupun tenaga penggerak pada alat tangkap bubu, jaring klitik maupun rawai dasar, diharapkan dapat dilakukan perluasan daerah operasi hingga perairan Laut Flores dan Samudera Hindia.

\section{KESIMPULAN DAN SARAN}

1. Teknologi penangkapan dalam usaha perikanan demersal di Kabupaten Lombok Barat masih tergolong tradisional. Hal tersebut mengakibatkan rendahnya produksi ikan, khususnya ikan demersal.

2. Pengembangan usaha penangkapan ikan demersal di Kabupaten Lombok Barat dapat dilakukan terhadap dua aspek, yaitu aspek teknologi dan manajemen. Pada masing-masing usaha penangkapan tersebut di atas, pengembangan yang dapat dilakukan adalah sebagai berikut:

a. Pada pancing Ladung, dapat dilakukan perbaikan manajemen usaha penangkapannya, yaitu dengan cara sistem armada semut seperti pada perikanan tuna dengan pancing tangan di Sorong.

b. Pada alat tangkap bubu, desainnya dapat mengadopsi dari bubu tipe Malaysia yang dioperasikan di perairan Natuna dan pengoperasiannya dengan menggunakan umpan. Selain itu jumlah bubu per unit penangkapan dapat ditambah hingga 20-30 buah, dengan ukuran kapal diperbesar hingga 5 GT atau lebih dengan kekuatan mesin sekitar 22 HP atau lebih.

c. Pada alat tangkap jaring klitik, pengoperasian malam hari dapat menggunakan alat bantu lampu. Selanjutnya jumlah tinting per unit usaha dapat ditingkatkan hingga mencapai sekitar 30 tinting. Ukuran kapal juga hendaknya diperbesar hingga 5 GT atau lebih dengan ke-kuatan mesin sekitar 22 HP atau lebih.

d. Sedangkan pada alat tangkap rawai dasar, jumlah mata pancing dapat diperbanyak hingga 3000 buah. Ukuran maupun desain kapal yang digunakan dapat mencontoh jenis kapal rawai yang telah umum digunakan di perairan Utara Jawa (Figure 2a). Pengembangan selanjutnya, adalah dengan cara penggunaan pesawat bantu line hauler kecil (baby line bauler) yang digerakkan dengan sistem hidrolik berkekuatan 5-6 HP. Pesawat bantu ini sudah banyak dipakai oleh nelayan pantai Utara Jawa.

3. Dengan pengembangan usaha penangkapan tersebut, maka perluasan daerah penangkapan ke perairan Laut Flores maupun Samudera Hindia dapat dilakukan. 


\section{DAFTAR PUSTAKa}

Anonim. 1994. Statistik Perikanan Indonesia Tahun 1994, Direktorat Jenderal Perikanan, Deptan, Jakarta.

Anonim. 1993. Laporan Tahunan Perikanan tahun 1992. Dinas Perikanan Kabupaten Lombok Barat.

Atmaja, S.B. 1994. Pengamatan hasil tangkapan jaring klitik dengan cahaya dan kemungkinan pengembangannya pada perikanan skala kecil. Jurnal Penelitian Perikanan Laut, Jakarta, No. 87, p.56-59.

Barus, H.R. dan Ch. Nasution. 1983. Percobaan penangkapan dengan jaring insang dasar di Pacitan. Laporan Penelitian Perikanan Laut, Jakarta, No.29, p.33-40.

Djamal, R. dan S. Marzuki. 1983. Pengamatan hasil tangkapan bubu Malaysia di perairan Natuna. Laporan Penelitian Perikanan Laut, Jakarta, No. 30, p.29-33.

Fridman, A.L. 1973. Theory and design of commercial fishing gear. Translated from Rusian, Israel Program for Scientific Transiation, Jerusalem.

Gunarso, W. 1985. Tingkah laku ikan dalam hubungannya dengan alat, metode dan taktik penangkapan. Jurusan Pemanfaatan Sumber Daya Perikanan, Fakultas Perikanan, IPB, Bogor.

Prado, J. and Dremier. 1990. Fishermans Workbook, Fishing News Books Ltd. Oxford, 1990, 180 hal.

Reppie, E. 1989. A mathematical study on catching mechanisms of pot fishery, Laboratory of Fisheries Resources Management System. Department of Marine Science and Technology, Tokyo University of Fisheries.

Widodo, J., S. Ilyas, N. Naamin, M. Badruddin, R. Djamal, S. Marzuki, I. Herianti, T. Suhendrata, Y.E. Herumurti, M.D.M. Pawarti, Y.Soselisa dan Sugiono. 1991. Petunjuk teknis pemanfaatan dan pengelolaan beberapa spesies sumber daya ikan demersal ekonomis penting (kakap merah, bawal putih, manyung dan petek). PHP/KAN/PT. 16/1991. Pusat Penelitian dan Pengembangan Perikanan, Jakarta.

Wijopriono dan H.H. Latif. 1993. Pengamatan terhadap beberapa aspek operasional rawai dasar di Juana, Jawa Tengah. Jurnal Penelitian Perikanan Laut, Jakarta, No.81. p.21-28. 